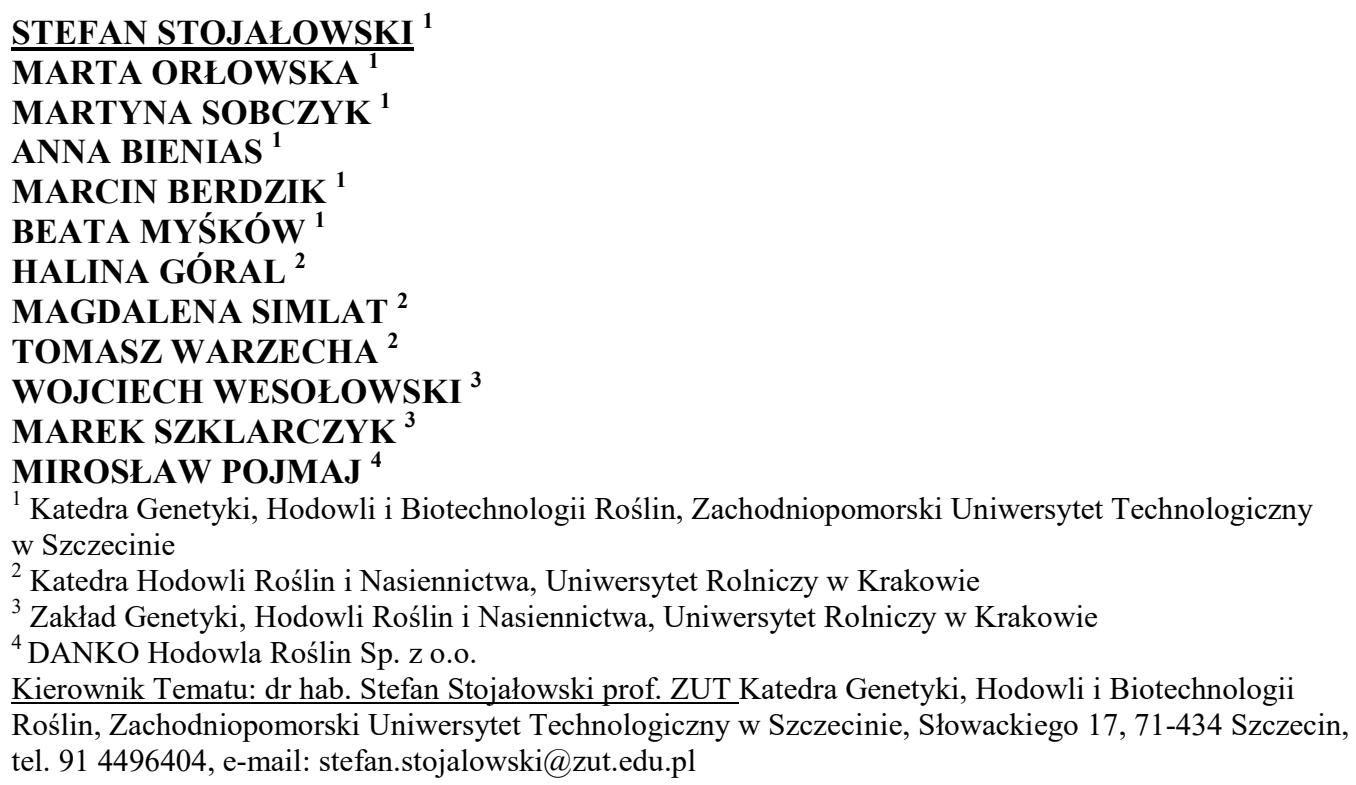

Prace zostaty wykonane $w$ ramach badań podstawowych na rzecz postępu biologicznego $w$ produkcji roślinnej na podstawie decyzji Ministra Rolnictwa $i$ Rozwoju Wsi nr HOR.hn.802.13.2018, Zadanie 83.

\title{
Genetyczne podłoże męskiej sterylności pszenżyta z różnymi cytoplazmami oraz możliwość wykorzystania badanych cytoplazm do tworzenia systemów CMS u pszenicy
}

Genetic background of male sterility in triticale with different cytoplasm's and perspectives of it utilization for development of CMS system in wheat

Słowa kluczowe: cytoplazmatyczna męska sterylność, odmiany mieszańcowe, pszenżyto 


\section{WSTĘP}

Pszenżyto jest syntetycznym gatunkiem uprawnym, który został stworzony przez człowieka. Jego popularność w produkcji rolniczej systematycznie rośnie. Wynika to $\mathrm{z}$ wielu zalet tego zboża. W hodowli komercyjnej duże nadzieje wiąże się z możliwością szerszego wdrożenia odmian mieszańcowych. Podstawą do zorganizowania produkcji nasiennej odmian heterozyjnych jest dostępność systemów cytoplazmatycznej męskiej sterylności (CMS). W przypadku pszenżyta największe nadzieje na praktyczne wykorzystanie systemów CMS wiąże się z cytoplazmami Triticum timopheevi i Aegilops sharonensis (Cauderon i in., 1985; Nalepa, 1990; Spiss i Góral, 1994; Warzecha i Góral, 2009). Jako alternatywę można wskazać cytoplazmę Pampa pochodzącą z żyta (Geiger i Schnell, 1970) i cytoplazmę Aegilops ventricosa. Lokalizacja genów przywracających płodność u pszenżyta z wyżej wymienionymi cytoplazmami sterylizującymi jest słabo poznana. Dotychczasowe badania dotyczące głównych genów restorerowych wykazały, że w cytoplazmie $T$. timopheevi są one zlokalizowane na chromosomie 6R (Curtis i Lukaszewski, 1993; Stojałowski i in., 2013), natomiast w cytoplazmie Pampa znajdują się one na chromosomach 4R, 1R i 3R (Miedaner i in., 2000; Hackauf i in., 2012).

\section{CELE ZADANIA}

- Oceny fenotypowe męskiej płodności/sterylności w obrębie czterech populacji mapujących $\mathrm{F}_{2} \mathrm{z}$ cytoplazmami T. timopheevi, CMS-Pampa, Ae. sharonensis i Ae. ventricosa oraz konstrukcja map sprzężeń dla dwóch populacji.

- Analizy sekwencyjne mitochondrialnego DNA pszenżyta z cytoplazmami normalną (T. aestivum), sterylizującą T. timopheevi i Pampa.

- Wytworzenie i oceny fenotypowe zestawu linii alloplazmatycznych pszenżyta oraz testowanie wybranych rodów hodowlanych pod kątem zdolności do utrzymywania męskiej sterylności i przywracania płodności w cytoplazmie T. timopheevi.

Badania nad kwitnieniem czterech populacji mapujących prowadzono na polu doświadczalnym Zachodniopomorskiego Uniwersytetu Technologicznego w Szczecinie. Ocenę fenotypową przeprowadzono $\mathrm{z}$ zastosowaniem 5-stopniowej skali bonitacyjnej (Góral, 2002). W okresie prowadzenia badań zaobserwowano nietypowe dla tego regionu warunki pogodowe. Czas kwitnienia poprzedził około 4-tygodniowy okres bez opadów, a samo kwitnienie przebiegało w czasie suszy i przy wysokich temperaturach powietrza. W rezultacie, rośliny kwitły bardzo dynamicznie - czas kwitnienia był krótki, a pylniki bardzo szybko zasychały. Prawdopodobnie z tego powodu wizualna ocena pylenia uniemożliwiła wytypowanie w pełni płodnych osobników (5 stopień płodności), pomimo to ocena zawiązywania ziaren pod izolatorami była u wielu roślin wysoka . Tylko siedem roślin z populacji mapującej z cytoplazmą $T$. timopheevi zostało ocenionych wzrokowo jako w pełni męskopłodne. U pozostałych mieszańców takich ocen nie zaobserwowano, pomimo iż każda z populacji liczyła powyżej 170 ocenionych pojedynków.

Analizy DArTseq i PCR wykonano w obrębie dwóch populacji mapujących. Z każdej wybrano po 90 osobników. Mapy chromosomów w populacji [CMS-Baltiko $\mathrm{P} \times$ 
DAD282/00] $\mathrm{F}_{2}$ mają długość od 37 do $130 \mathrm{cM}$. Długości zmapowanych chromosomów mieszańca [CMS-Salvo 15/1 T $\times$ DAD282/00] $\mathrm{F}_{2}$ mieszczą się $\mathrm{w}$ granicach od $33 \mathrm{cM}$ do $112 \mathrm{cM}$. W trakcie analiz kilka grup sprzężeń zostało przypisanych do tych samych chromosomów, ale też nie wszystkie chromosomy pszenżyta zostały ujęte na mapach.

Dane sekwencyjne mtDNA uzyskano dla trzech cytoplazm, następnie złożono je w kontigi oraz skafoldy (złożenia wyższego rzędu). Uzyskano kilka alternatywnych układów złożonych sekwencji, Jest to rezultatem występowania w genomach mitochondrialnych sekwencji powtórzonych.

Wśród wytworzonych linii alloplazmatycznych rosnących i ocenianych fenotypowo na poletkach doświadczalnych w Krakowie, linia DAD 1 w każdej cytoplazmie była męskopłodna. Indeks restoracji zawierał się w granicach 70,0-95,0\%. Linia Salvo 15 była w pełni męskosterylna. Pozostałe dwie linie wykazały specyficzną reakcję w zależności od rodzaju cytoplazmy. Linia Baltiko 1 była męskosterylna w cytoplazmie Pampa i męskopłodna w cytoplazmie Ae. sharonensis, natomiast linia Zorro 1 męskosterylna w cytoplazmach Pampa i Ae. sharonensis oraz męskopłodna w cytoplazmach T. timopheevi i Ae. ventricosa.

\section{WNIOSKI}

1. Stworzono mapy genetyczne dwóch populacji mapujących pokrywające większą część genomu pszenżyta.

2. W wyniku analiz bioinformatycznych uzyskano kilka alternatywnych wersji sekwencji mtDNA pszenżyta.

3. Cytoplazmy sterylizujące CMS-T, CMS-P, CMS-A i CMS-V mogą być wykorzystane do tworzenia stabilnych fenotypowo linii męskosterylnych pszenżyta.

\section{LITERATURA}

Cauderon Y., Cauderon A., Gay G., Roussel J. 1985. Alloplasmic lines and nucleo-cytoplasmic interactions in triticale. In: Genetics and breeding of triticale, Eucarpia Meeting, Clermont-Ferrand, France. July 2-5, 1984. INRA, Paris: 177 - 191.

Curtis C. A., Lukaszewski A. J. 1993. Localization of genes in rye that restore male fertility to hexaploid wheat with T.timopheevi cytoplasm. Plant Breeding 111: $106-112$.

Geiger H. H., Schnell F. W. 1970. Cytoplasmic male sterility in rye (Secale cereale L.). Crop Sci. $10: 590$ 593.

Góral H. 2002, Biologiczno-hodowlane aspekty wykorzystania heterozji u pszenżyta (x Triticosecale Wittmack). Zeszyty Nauk. AR im. H. Kołłątaja w Krakowie, Rozprawy z. 283.

Hackauf B., Korzun V., Wortmann H., Wilde P., Wehling P. 2012. Development of conserved ortholog set markers linked to the restorer gene Rfp1 in rye. Mol. Breeding 30: 1507-1518.

Miedaner T., Glass C., Dreyer F., Wilde P., Wortmann H., Geiger H. H. 2000. Mapping of genes for malefertility restoration in 'Pampa' CMS winter rye (Secale cereale L.). Theor. Appl. Genet. 101: 1226 1233.

Nalepa S., 1990 Hybrid triticale: present and future. Proc. 2nd International Triticale Symposium, Passo Fundo, Rio Grande do Sul, Brasil, 1-5 October 1990: 402 - 407.

Spiss L., Góral H. 1994, Breeding of male sterile and fertility restoring forms of triticale. Zesz. Nauk. AR Szczecin 162: $243-246$. 
Stojałowski S., Bobrowska A., Hanek M., Myśków B. 2013. The importance of chromosomes from the sixth homeologic group in the restoration of male fertility in winter triticale with Triticum timopheevii cytoplasm. J. Appl. Genetics 54: $179-184$.

Warzecha T., Góral H. 2009. Otrzymywanie mieszańców z krzyżowań zwrotnych heksaploidalnej pszenicy z cytoplazmą Aegilops sharonensis z pszenżytem. W: Genetyka i genomika w doskonaleniu roślin uprawnych. B. Naganowska, P. Kachlicki, P. Krajewski (red.), Instytut Genetyki Roślin PAN w Poznaniu, ISBN 978-83-61607-36-6, ISSN 1230-0721:305-311. 